\title{
Konstruksi citra partai Islam pada pemilu 2014 pendekatan fikih-siyasah
}

\author{
Iding Rosyidin dan Gun Gun Heryanto \\ Fakultas Ilmu Sosial dan Ilmu Politik, UIN Syarif Hidayatullah Jakarta \\ E-mail:iding.rosyidin@uinjkt.ac.id
}

The research of the Image Construction of Islamic Political Party at 2014 Election in Indonesia aimed at knowing the image construction of Islamic political party, especially at Republika and Sindo newspaper. The thoeries used in this research are fikih siyasat (the characteristic of muslim leader), social construction of mass media and hierarchy of influence by using discourse analysis as an analytical technique. The method of the research is qualitative. And the Informans as research subject are the jurnalist, redaction and management representative of both newspaper.The founds of research showed that the news characteristic of both newspaper were almost same. From the social cognition there were a difference. Republika strived to counter every news related to the image of Islamic political party and Sindo did not. From the social context, the background of this news was 2014 Election. And from hierarchy of influence perspective, the impact of media organization level was strong as shown in the power of the owner like Hary Tanoe in Sindo as a chairman of MNC Group. So, Sindo never produced news that contradicted to Hary or Hanura Party. The impact of ideological level also strong as we can see in the news of Republika which not only related to the profit, but also the benefit of Islamic Party.

Penelitian konstruksi citra partai politik Islam di Pemilu 2014 di Indonesia bertujuan untuk mengetahui pembangunan citra partai politik Islam, terutama di koran Republika dan Sindo. Teori-teori yang digunakan dalam penelitian ini adalah fikih siyasat (karakteristik pemimpin muslim), konstruksi sosial media massa dan hirarki pengaruh dengan menggunakan analisis wacana sebagai teknik analitis. Metode penelitian ini adalah kualitatif. Informan sebagai subjek penelitian adalah jurnalist, redaksi dan manajemen perwakilan dari kedua surat kabar. Temuan dari penelitian menunjukkan bahwa karakteristik berita dari kedua surat kabar hampir sama. Dari kognisi sosial ada perbedaan. Republika diupayakan untuk melawan setiap berita yang terkait dengan citra partai politik Islam dan Sindo tidak. Dari konteks sosial, latar belakang berita ini adalah Pemilu 2014. Dan dari hirarki perspektif pengaruh, dampak dari tingkat organisasi media yang kuat seperti yang ditunjukkan pada kekuatan pemilik seperti Hary Tanoe di Sindo sebagai ketua MNC Group. Jadi, Sindo tidak pernah memroduksi berita yang bertentangan dengan 
ljtihad, Jurnal Wacana Hukum Islam dan Kemanusiaan, Volume 15, No. 1, Juni 2015: 1-20

Hary atau Partai Hanura. Dampak dari tingkat ideologis juga kuat seperti yang kita lihat dalam berita Republika yang tidak hanya berkaitan dengan keuntungan, tetapi juga manfaat dari Partai Islam.

Keywords: Construction; Image; Islamic party; Hierarchy of influence; Discourse analysis

\section{Pendahuluan}

Di sebuah negara Islam atau yang mayoritas penduduknya beragama Islam keberadaan partai-partai Islam atau berbasis massa Islam memiliki makna yang penting. Partai-partai Islam yang dimaksud adalah PKS, PPP dan PBB yang secara tegas mencantumkan Islam sebagai asasnya. PPP yang merupakan fusi dari partai-partai Islam pada masa Orde Baru pernah menggantikan asasnya dengan Pancalisa dengan mengganti pula lambangnya dari Ka'bah menjadi bintang. Tetapi sejak masa reformasi PPP kembali ke jati dirinya semula, berasaskan Islam dan berlambangkan Ka'bah. Sedangkan partai-partai berbasis massa Islam adalah PAN dan PKB yang mencantumkan Pancasila sebagai asasnya tetapi sebagian besar konstituennya adalah kalangan Islam. Meskipun kedua partai ini menyatakan terbuka terhadap semua kalangan termasuk non-muslim, tetapi faktnya mayoritas pemilihnya tetap umat Islam, lebih khusus warga NU untuk PKB dan Muhammadiyah untuk PAN. Keberadaan partai-partai Islam tersebut dapat dipandang sebagai representasi dari para warga negara Muslim yang tentu memiliki berbagai macam aspirasi politik yang hendak diwujudkan. Peran partai politik antara lain untuk mengagregasi kepentingan-kepentingan umat Islam jelas tidak dapat diabaikan, bahkan menjadi peran kunci.

Dalam pandangan fikih siyasah, keberadaan dan peran partai-partai Islam jelas sangat diperlukan. Fikih siyasah sebagai ilmu yang mempelajari hal ikhwal dan seluk beluk pengaturan urusan umat dan negara dengan segala bentuk hukum, peraturan dan kebijaksanaan yang dibuat oleh pemegang kekuasaan yang sejalan dengan dasar-dasar ajaran dan ruh syariat untuk mewujudkan kemasalahatan umat (Pulungan, 2002: 26), tentu menganggap penting peran partai-partai Islam. Partai Islamlah yang seyogianya tampil di depan untuk mengatur urusan umat dan negara khususnya yang terkait dengan kepentingan Islam.

Sayangnya partai-partai politik Islam atau berbasis massa Islam di Indonesia dalam kurun waktu terakhir belum mampu menunjukkan performa yang menggembirakan. Sementara itu, partai-partai Islam juga kurang mendapatkan pemberitaan yang baik (good news) di me- 
dia-media massa baik pada tingkat nasional maupun lokal. Hal ini boleh jadi disebabkan antara lain karena hampir tidak adanya raihan prestasi atau gebrakan-gebrakan politik yang ditampilkan oleh partai-partai Islam tersebut, yang kemudian dapat diapresiasi dengan baik oleh publik. Dengan kata lain, partal-partai Islam seolah-olah tenggelam oleh berbagai pemberitaan tentang parpol-parpol lainnya, khususnya dari kalangan partai-partai nasionalis.

Tidak heran kalau partai-partai Islam diduga tidak akan mampu bersaing dengan partaipartai nasionalis dalam Pemilu 2014. Salah satu hasil survei yang dirilis oleh salah satu lembaga survei, yaitu Lingkaran Survei Indonesia (LSI), misalnya, menyebutkan bahwa partai-partai Islam tidak akan mampu mendapatkan suara lebih dari 5 persen. Menurut survei yang dilakukan pada 1 - 8 Maret 2013 tersebut PKB memeroleh 4,5 persen, PPP meraih 4,0 persen, PAN mendapatkan 4,0 persen, dan PKS hanya meraih 3,7 persen.

Beberapa media massa nasional kemudian menurunkan berita terkait dengan rilis hasil survei tersebut dengan kalimat-kalimat yang cenderung menyudutkan partai-partai Islam atau berbasis massa Islam. Di Harian Kompas, misalnya, judul pemberitaan (headline) adalah “Krisis Kepempimpinan Partai Islam Belum Usai," sementara Harian Republika menurunkan judul tulisan dengan frasa "Partai Islam Alami Masa Kritis." Demikian pula judul di mediamedia massa lainnya hampir memperlihatkan nada yang serupa.

Selain itu, ada pula kasus yang sangat memprihatinkan terkait pemberitaan-pemberitaan tentang partai-partai Islam atau berbasis massa Islam di media-media massa yang cenderung memperlihatkan sisi keburukan (bad news), yaitu kasus korupsi yang melibatkan bukan saja kader melainkan tokoh partai Islam. Hal ini, misalnya, terjadi ketika Presiden Partai Keadilan Sejahtera (PKS), Lutfie Hasan Ishaaq, ditangkap oleh Komisi Pemberantasan Korupsi (KPK) karena dugaan korupsi kasus impor daging sapi. Tentu saja penangkapan tersebut mendapatkan pemberitaan yang seluas-luasnya di media-media massa karena memiliki nilai berita (media value) yang tinggi (McQuail, 2002: 64).

Penangkapan Lutfie jelas sangat berpengaruh terhadap citra partai Islam. Ketua PP Muhammadiyah, Din Symasuddin, dalam sebuah wawancara mengatakan bahwa kasus tersebut bukan hanya berdampak pada diri pribadi Lutfie sendiri, melainkan juga partainya, yakni PKS dan partai-partai Islam secara keseluruhan (Metronews.com, 1 Februari 2013, diakses pada 25 Maret 2013). Kasus-kasus korupsi apalagi yang menimpa partai-partai 
ljtihad, Jurnal Wacana Hukum Islam dan Kemanusiaan, Volume 15, No. 1, Juni 2015: 1-20

Islam seperti PKS tentu saja akan menjadi masalah besar terutama menyangkut citra partaipartai tersebut di mata publik. Bukan tidak mungkin citra partai-partai tersebut akan semakin merosot di masa mendatang setidaknya pada Pemilu 2014 yang tinggal menyisakan waktu kurang lebih satu setengah tahun.

Dari sudut pandang fikih-siyasah, munculnya sejumlah elite politik Islam yang terkena kasus korupsi jelas merupakan aib yang besar. Para peletak pemikiran politik Islam seperti al-Mawardi, misalnya, sangat ketat dalam memberikan karakteristik pemimpin-pemimpin atau elite-elite Islam. Selain memiliki keadilan (al-'adālah), al-Mawardi menyebutkan bahwa pemimpin Islam seharusnya memiliki pandangan yang menekankan pada pengaturan rakyat dan kemasalahatan bersama (al-Mawardi: 6). Pemimpin yang melakukan korupsi, dengan demikian, tidak dapat digolongkan ke dalam orang yang memiliki karakteristik kepemimpinan Islam seperti digambarkan al-Mawardi.

Berbagai pemberitaan media massa yang terkait dengan citra partai-partai Islam atau berbasis massa Islam tentu tidak dapat dilepaskan dari konstruksi sosial media massa. Menurut teori konstruksi sosial media massa yang bersumber dari teori konstruksi sosial dari Peter L. Berger dan Thomas Luckman (1966: 42) realitas di media massa adalah realitas konstruktif. Artinya, apapun yang disajikan oleh media massa, baik dalam bentuk pemberitaan, iklan, editorial dan sebagainya merupakan hasil konstruksi dari para redaktur media massa tersebut.

Berdasarkan pada latar belakangan permasalahan tersebut, peneliti tertarik untuk melakukan penelitian dengan judul Konstruksi Citra Partai-Partai Islam atau Berbasis Massa Islam di Media-Media Nasional: Pemetaan Pemilu 2014. Media massa nasional dalam penelitian ini hanya dibatasai pada dua harian nasional, yaitu Republika dan Sindo. Alasan dipilihnya kedua harian tersebut adalah bahwa yang pertama, yakni Republika mewakili media yang membawa kepentingan Islam sedangkan yang kedua, Sindo, mewakili media yang bersifat netral.

Rumusan masalah penelitian ini adalah sebagai berikut: Pertama, bagaimana konstruksi citra partai-partai Islam atau berbasis massa Islam di Harian Republika dan Sindo? Kedua, bagaimana hierarki pengaruh dalam konstruksi citra partai-partai Islam atau berbasis massa Islam di Harian Republika dan Sindo? Adapun tujuan penelitian ini adalah untuk mengetahui konstruksi citra partai-partai Islam atau berbasis massa Islam, khususnya di media-media 
massa nasional, yakni Republika dan Sindo dan mengetahui hierarki pengaruh dalam konstruksi citra partai-partai Islam atau berbasis massa Islam di media-media massa nasional, yaitu Republika dan Sindo

Landasan teoretis dan konseptual yang digunakan dalam penelitian ini adalah fikih siyasah, terutama dari al-Mawardi dalam karyanya al-Aḥkam al-Sultaniyyah, khususnya yang terkait dengan karakteristik kepemimpinan Islam. Para pemikir politik Islam pada masa klasik umumnya berbicara selain tentang asal-usul terbentuknya negara, adalah tentang siapa orang yang berhak untuk memimpin negara dan umat Islam. Selain al-Mawardi, dikenal juga pemikir-pemikir politik Islam lainnya, seperti Abi Rabi, al-Ghazali dan Ibn Khaldun.

Pandangan tentang karaktetistik kepemimpinan Islam, khususnya dari al-Mawardi tampaknya masih sangat relevan untuk diterapkan dalam konteks politik Indonesia. Hal ini karena adanya partai-partai baik yang menamakan dirinya sebagai benar-benar partai Islam karena berasaskan Islam maupun yang basis pendukungnya mayoritas umat Islam sekalipun dasar negaranya bukanlah Islam. Karakteristik kepemimpinan Islam menjadi penting karena dalam derajat tertentu dapat memberikan pengaruh terhadap citra partai Islam tersebut di mata umat.

Teori lainnya adalah teori konstruksi sosial media massa dari Peter L. Berger dan Thomas H. Luckman dan teori hirarki pengaruh dari Pamela J. Shoemaker dan Stephen D. Reese sedangkan teknik analisisnya menggunakan analisis wacana Van Dijk. Teori dan pendekatan konstruksi sosial atas realitas Peter L Berger dan Luckmann telah direvisi dengan melihat fenomena media massa sangat substantif dalam proses eksternalisasi, subyektivasi dan internalisasi inilah yang kemudian dikenal sebagai "konstruksi sosial media massa". Menurut perspektif ini tahapan-tahapan dalam proses konstruksi sosial media massa itu terjadi melalui: (a) tahap menyiapkan materi konstruksi; (b) tahap sebaran kostruksi; (c) tahap pembentukan kosntruksi; (d) tahap konfirmasi (Bungin, 2002: 205). 


\section{Gambar 1: Proses Konstruksi Sosial Media Massa}

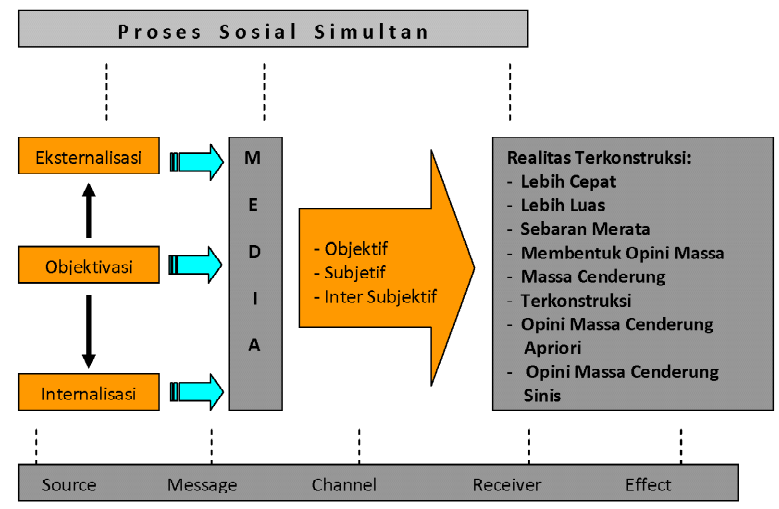

Tahap menyiapkan materi konstruksi: Ada tiga hal penting dalam tahapan ini yakni: keberpihakan media massa kepada kapitalisme, keberpihakan semu kepada masyarakat, keberpihakan kepada kepentingan umum.

Tahap sebaran konstruksi: prinsip dasar dari sebaran konstruksi sosial media massa adalah semua informasi harus sampai pada khalayak secara tepat berdasarkan agenda media. Apa yang dipandang penting oleh media, menjadi penting pula bagi pemirsa atau pembaca.

Tahap pembentukan konstruksi realitas. Pembentukan konstruksi berlangsung melalui: (1) konstruksi realitas pembenaran; (2) kedua kesediaan dikonstruksi oleh media massa; (3) sebagai pilihan konsumtif.

Tahap Konfirmasi. Konfirmasi adalah tahapan ketika media massa maupun khalayak memberi argumentasi dan akuntabilitas terhadap pilihannya untuk terlibat dalam pembetukan konstruksi.

Sedangkan teori hirarki pengaruh memfokuskan pembahasannya pada isi media. Isi dari media massa seperti berita televisi merupakan bagian penting yang terbuka dan memiliki akses untuk dipelajari. Proses komunikasi massa pada isi atau content berita televisi merupakan bagian yang cukup jelas untuk dipelajari, seperti latar belakang sebuah keputusan yang berasal dari para pekerja media televisi, organisasi perusahaan televisi, atau pun pengaruh yang berasal dari luar organisasi stasiun tv yang bersangkutan.

Teori Hierarki Pengaruh pertama kali diungkapkan oleh Pamela J. Shoemaker \& Stephen D. Reese. Teori ini menjelaskan bahwa isi (content) dari media massa dipengaruhi oleh beberapa 
faktor yang luas dari dalam dan luar organisasi media ("media content, is influenced by a wide variety of factors both inside and outside media organizations") (Shoemaker \& Reese, 1996: 11). Ada lima level yang memengaruhi teks-teks media, yaitu individu (redaksi, wartawan); rutinitas media (lingkungan kerja di media terkait); level organisasi (termasuk pemilik atau owner yang paling berpengaruh); ektra media (organisasi lain di luar organisasi media itu sendiri termasuk negara); dan ideologi (nilai-niali dan filosofi hidup yang dianut oleh media massa terkait. Kelima level hierarki tersebut saling memberikan pengaruh terhadap apa yang disajikan media.

Media massa merupakan organisasi sosial yang secara internal memiliki standar kualitas penilaian, struktur, dan hirarki dalam menjalankan mekanisme kerjanya. Mekanisme serta pilihan politik representasi yang dijalankan media memberi penegasan bahwa secara intraorganisasi, media pasti bersikap aktif dan bahkan penuh kontradiksi serta konflik di dalamnya. Sementara secara ekstra-organisasi, media bersifat interdependen karena saling mempengaruhi dengan berbagai institusi sosial lain di luar dirinya (http://www2.kompas.com/kompascetak/0407/19/swara/1136657.html. Diakses pada tanggal 23 oktober 2008 ).

Dalam menganalisis isi suatu media, terdapat lima perspektif mengenai tahapan yang berpengaruh terhadap isi suatu media (Shoemaker \& Reese, 1996: 105), yaitu sebagai berikut:

\section{Individual media workers level}

Dalam tahapan ini, sikap, kepentingan, dan latar belakang pekerja media dianggap mempengaruhi isi media. Para pekerja media seperti, redaktur, wartawan memiliki peran yang sangat penting dalam menentukan isi media. Mereka memiliki orientasi tertentu dalam mengambil keputusan atau menentukan isi media. Tiga hal mendasar dari para pekerja media yang berpengaruh terhadap isi media yaitu, karakteristik dan latar belakang, kebiasaan serta nilai atau kepercayaan (agama), dan orientasi atau profesionalisme para pekerja media.

\section{Media routines level}

Rutinitas para pekerja media cetak dalam membuat pemberitaan dianggap mempengaruhi isi media. Suatu rutinitas akan menimbulkan dampak positif atau negatif. Dalam media, dampak rutinitas dilihat dari tiga hal yaitu, apa yang diterima oleh pembaca, kapabilitas 
organisasi media dalam menghasilkan atau membuat pesan berita, serta produk apa yang tersedia (naskah, pemilihan narasumber, gambar dll.).

Rutinitas yang dimaksud adalah kuantitas atau frekwensi pekerja media sebuah media cetak atau organisasi media dalam memproduksi sebuah berita. Tingkat rutinitas yang tinggi dapat berpengaruh buruk terhadap kualitas isi media dikarenakan kurangnya observasi tentang realitas yang akan diangkat. Dalam tingkatan ini pula dapat dilihat tujuan yang ingin dicapai oleh industri media, apakah berdasarkan kepada kualitas naskah yang mengedepankan suatu realitas, atau hanya berorientasi keuntungan semata.

\section{Organization level}

Pada tingkatan organisasi, pemilik atau pemegang saham memiliki kekuatan paling besar dalam pengambilan keputusan atau kebijakan. Hal tersebut akan sangat berpengaruh terhadap isi suatu media. Kepemilikan suatu organisasi dapat terdiri dari perseorangan atau lebih. Semakin besar saham yang dimiliki, semakin besar pula pengaruh kekuasaan yang dimiliki. Dalam industri media, sebuah media cetak memiliki identitas sendiri yang biasanya identik dengan pemiliknya. Isi media (media content) yang dihasilkannya juga cenderung dipengaruhi oleh kepemilikan rumah produksi itu.

\section{Extramedia level}

Seperti yang dijelaskan di atas, bahwa kekuatan atau kebijakan dari pihak luar organisasi media memiliki pengaruh terhadap kinerja media televisi. Hal tersebut dipercaya memiliki pengaruh terhadap isi media. Pengaruh yang berasal dari eksternal bukan hanya terbatas pada unsur politik saja, tetapi berkaitan dengan permodalan atau profit. Kebijakan pemerintah atau negara juga memiliki pengaruh yang sangat kuat terhadap isi media. Negara, misalnya, merupakan pihak eksternal yang cukup berpengaruh terhadap isi media di sebuah media.

\section{Ideological level}

Definisi ideologi menurut Raymond Williams seperti yang dikutip oleh Pamela J. Shoemaker \& Stephen D. Reese : "ideology as a 'relatively formal and articulated system of meanings, values, and beliefs, of a kind that can be abstracted as a 'world view' or a 'Class outlook" (Shoemaker \& Reese, 1996: 122). (ideologi merupakan sebuah relativitas dan sekumpulan suatu sistem dari 
arti, nilai, dan kepercayaan yang dapat digambarkan sebagai sebuah cara pandang terhadap dunia luar dan sekitarnya). Pada tahapan ini, ideologi seseorang atau suatu organisasi media memiliki pengaruh terhadap isi media. Nilai-nilai serta kepercayaan yang dijadikan sebagai landasan mereka memiliki pengaruh yang cukup besar. Media massa seperti televisi merupakan wujud dari apa yang dilihat di sekitarnya sebagai suatu realitas dan digambarkan menurut ideologi atau cara pandang mereka.

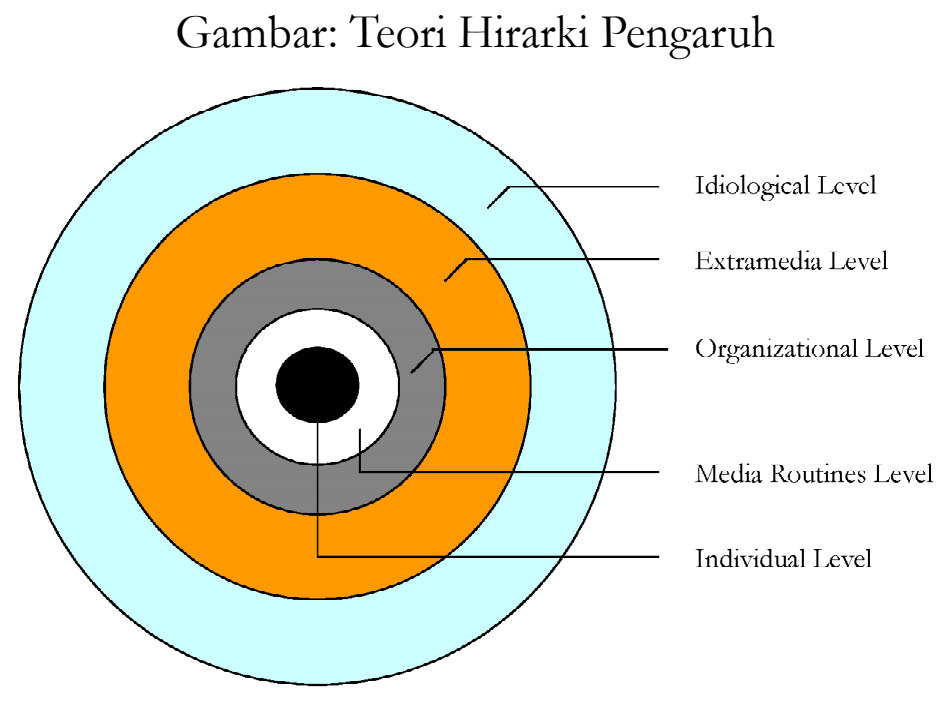

\section{Metode penelitian}

Dalam penelitian ini yang menjadi subyek penelitiannya adalah para pekerja media, representasi manajemen (organisasi perusahaan) baik yang ada di Harian Republika dan Sindo. Ada pun yang menjadi obyek penelitian adalah wacana pemberitaan tentang partai-partai Islam atau berbasis massa Islam.

Dalam penelitian ini metode yang digunakan adalah metode penelitian kualitatif. Metode kualitatif merupakan suatu prosedur penelitian yang menghasilkan sejumlah data deskriptif, baik yang tertulis maupun lisan dari orang-orang serta tingkah laku yang diamati. Dalam hal ini individu atau organisasi harus dipandang sebagai bagian dari suatu keseluruhan. Artinya tidak boleh diisolasikan ke dalam variabel atau hipotesis. 
Menurut Crasswell sebagaimana dikutip oleh Eriyanto, beberapa asumsi dalam pendekatan kualitatif yaitu pertama, peneliti kualitatif lebih memperhatikan proses daripada hasil. Kedua, peneliti kualitatif lebih memerhatikan interpretasi. Ketiga, peneliti kualitatif merupakan alat utama dalam mengumpulkan data dan analisis data serta peneliti kualitatif harus terjun langsung ke lapangan, melakukan observasi partisipasi di lapangan. Keempat, peneliti kualitatif menggambarkan bahwa peneliti terlibat dalam proses penelitian, interpretasi data dan pencapaian pemahaman melalui kata atau gambar (Eriyanto, 2001: 3).

Ada tiga komponen yang menjadi unit analisis dalam penelitian in, yakni pertama adalah teks yakni teks pemberitaan di Harian Republika dan Sindo. Unit analisis kedua adalah kognisi sosial pembuat program berita di kedua harian tersebut dalam hal ini adalah cara pandang para pekerja media terkait dengan pemberitaan partai-partai Islam. Ketiga adalah unit konteks sosial yang melatarbelakangi pemberitaan partai-partai Islam

Untuk teknik pengumpulan data digunakan langkah-langkah berikut: Documentation: caranya mengumpulkan dokumen-dokumen terkait dengan teks-teks pemberita di Harian Republika dan Sindo dan dokumen pendukung lainnya yang relevan dengan substasni penelitian. Depth interviewing: wawancara mendalam dengan key informan yang relevan dengan substansi masalah penilitian. Adapun wawancara mendalam dilakukan dengan reporter, pimpinan redaksi dan wakil manajemen perusahaan. Unstructure observation, observasi langsung tidak terstruktur dengan mengamati perkembangan-perkembangan yang terjadi di kedua harian tersebut (Arikunto, 2002: 133). Observasi dalam penelitian ini dilakukan lebih pada observasi teks dalam kaitannya dengan konstruksi social media massa dan hirarki pengaruh atas isi media.

Data yang diperoleh dianalisis melalui tiga alur kegiatan yang akan dilakukan secara bersamaan, yakni melalui redukasi data, penyajian data, dan penarikan kesimpulan serta verifikasi.

Reduksi data merupakan sebuah proses pemilihan, pemusatan perhatian pada penyederhanaan, pengabstraksian dan transformasi data kasar yang muncul dari catatancatatan tertulis di lapangan. Data kualitatif disederhanakan dan ditransformasikan dalam aneka ragam cara, seperti seleksi dan penyortiran ketat ringkasan atau uraian singkat penggolongan dengan mencari pola yang lebih luas. 
Penyajian data merupakan susunan sekumpulan informasi yang memungkinkan penarikan kesimpulan dan pengambilan tindakan. Peneliti berupaya menggunakan matriks teks, grafik, jaringan dan bagan, di samping teks naratif.

Analisa data kualitatif mulai dengan mencari arti benda-benda, mencatat keteraturan, pola-pola, penjelasan, konfigurasi-konfigurasi yang mungkin, alur sebab-akibat, dan proposisi. Peneliti akan menarik kesimpulan-kesimpulan secara longgar, tetap terbuka dan skeptis namun kemudian meningkat menjadi lebih rinci dan mengakar dengan kokoh. Kesimpulan tersebut diverifikasi selama proses penelitian melalui peninjuan atau pemikiran kembali pada catatan lapangan secara terperinci dan seksama, bertukar pikiran dengan informan peneliti. Maknamakna yang muncul dari data harus diuji kebenarannya, kekokohannya dan kecocokannya sehingga membentuk validitasnya.

Setelah data diperoleh, maka selanjutnya adalah melakukan analisis data. Adapun analisis data yang digunakan dalam penelitian ini dalah analisis wacana. Wacana sendiri dapat dipahami sebagai rekaman kebahasaan yang utuh tentang persitiwa komunikasi, biasanya terdiri atas seperangkat kalimat yang mempunyai hubungan pengertian yang satu dengan yang lain. Komunikasi itu dapat menggunakan bahasa lisan dan dapat pula memakai bahasa tulisan (Sobur, 2010:10).

Dalam penelitian ini menggunakan analisa wacana model Teun A. Van Dijk. Menurut Van Dijk analisis wacana tidak cukup didasarkan pada analisis teks semata, karena teks hanyalah hasil dari suatu praktik produksi yang harus juga diamati. Di sini harus dilihat juga bagaimana suatu teks diproduksi, sehingga memperoleh suatu pengetahuan kenapa teks bisa semacam itu. Wacana model Van Dijk ini yang terdiri dari tiga elemen, yaitu teks, kognisi sosial, dan konteks sosial. Elemen teks, terdiri dari: Struktur Makro, yaitu makna global dari suatu teks yang dapat diamati dari topik/tema yang diangkat oleh suatu teks, elemennya adalah Tematik. Superstrukur, yaitu kerangka suatu teks, seperti bagian pendahuluan, isi, penutup, dan kesimpulan, elemennya adalah skematik. Sementara elemen StrukturMikro, makna lokal dari suatu teks yang dapat diamati dari pilihan kata, kalimat dan gaya yang dipakai oleh suatu teks, elemennya adalah Semantik, Sintaksis, Stalistik, Retoris. 


\section{Tabel 1: Struktur Wacana}

\begin{tabular}{|c|c|c|}
\hline Struktur wacana & IIal yang diamati & Elemen \\
\hline Struktur Makro & $\begin{array}{l}\text { I'ematik: } \\
\text { Tema/topik yang dikedepankan dalan suatu } \\
\text { ceita }\end{array}$ & Topik \\
\hline Superstruktur & $\begin{array}{l}\text { Skematik: } \\
\text { Bagaimana bagian dan urutan corita } \\
\text { diskemakan dalam Leks (skenario) cerita LItık }\end{array}$ & Skema \\
\hline \multirow[t]{4}{*}{ Struktur Mikro } & $\begin{array}{l}\text { Scmantik : } \\
\text { Makna yang ingirn ditekankan dalarn teks } \\
\text { cerita diskemakan dalam teks (skenario) } \\
\text { cerita utul }\end{array}$ & $\begin{array}{l}\text { Latar, dctail, maksud, praanggapan, } \\
\text { mominnalisasi }\end{array}$ \\
\hline & $\begin{array}{l}\text { Sintaksis : } \\
\text { Bagaimana kalimat (bentuk susunan) yang di } \\
\text { dipilih }\end{array}$ & Bentuk kalinat, koherensi, dan kat ganti \\
\hline & $\begin{array}{l}\text { Stilistik : } \\
\text { Bagaimana pilihan kata yang dipakai dalam } \\
\text { tcks (Cinsal sripl) corita }\end{array}$ & Leksikon \\
\hline & $\begin{array}{l}\text { Rhatoris : } \\
\text { Bagairnana darn dengarn cara apa penekantan } \\
\text { dilakıkin }\end{array}$ & Grafis, Mtcfora, Ekspresi \\
\hline
\end{tabular}

Elemen kognisi didasarkan pada asumsi bahwa teks tidak mempunyai makna, tetapi makna itu diberikan oleh pemakai bahasa, atau lebih tepatnya proses kesadaran mental dari pemakai bahasa. Oleh karena itu, dibutuhkan suatu penelitian atas representasi kognisi dan strategi pembuat pesan dalam memproduksi suatu pesan. Karena setiap teks terlebih pada pemberitaan pada dasarnya dihasilkan lewat kesadaran, pengetahuan, prasangka atau pengetahuan tertentu atas suatu peristiwa. Dalam kognisi ini ada skema/model yang dimaksud, yakni : (1) skema person (person schemes) berhubungan dengan bagaimana seseorang mencitrakan dan memandang orang lain. (2) Skema diri (self schemes), skema ini berhubungan dengna bagaimana individu memahami dirinya sendiri. (3) Skema peran (role shemes) skema yang berhubungan dengan bagaimana invidu memandang dan menggambarkan peranan dan posisi yang ditempati seseorang dalam masyarakt. Skema peristiwa (event Schemes) yang berhubungan dengan proses individu menafsirkan sebuah peristiwa.

Elemen terakhir adalah konteks sosial. Wacana selalu berkembang, sehingga untuk meneliti teks diperlukan analisis intertekstual dengan meneliti bagaimana wacana tentang suatu hal diproduksi dan dikonstruksikan dalam masyarakat. 


\section{Karakteristik pemberitaan}

Pemberitaan tentang partai-partai Islam atau berbasis massa Islam mendapatkan porsi yang cukup besar dari Harian Republika dan Sindo. Hal ini terutama ketika partai-partai tersebut mendapatkan posisi yang kurang baik dalam berbagai survei yang dilakukan lembaga-lembaga survei. Kesemua lembaga survei tersebut melansir bahwa partai-partai Islam tersebut diprediksi akan mengalami keterpurukan pada Pemilu 2014. Terlepas dari berbagai faktor yang menjadi penyebab kemerosotan partai-partai Islam, realitas social tersebut pada gilirannya mendapatkan perhatian yang cukup luas dari media massa termasuk Harian Republika dan Sindo.

'Baik Harian Republika maupun Sindo yang notabene merupakan harian nasional tentu menjadikan realitas sosial yang menimpa partai-partai Islam atau berbasis massa Islam sebagai objek pemberitaan. Bahkan keduanya memberikan rukrik khusus meskipun tentu saja dengan penekanan dan penonjolan yang tidak sama di antara keduanya. Harian Republika yang memang dikenal sebagai koran umat agaknya lebih banyak memberikan porsi pemberitaan yang besar terhadap partai-partai Islam. Di sini Republik tampaknya memosisikan dirinya sebagai dekat dengan partai Islam karena kesamaan ideologinya dan masih menyimpan harapan terhadap keberadaan partai Islam yang bisa diharapkan mampu memerankan dirinya seperti yang diinginkan oleh umat Islam.

Berikut ini adalah sampel pemberitaan tentang partai Islam di Harian Republika dan Sindo:

\section{Tabel 2: Sampel Berita Republika}

\begin{tabular}{|c|c|c|}
\hline $\mathrm{NO}$ & $\begin{array}{l}\text { Tanggal } \\
\text { Tayang }\end{array}$ & $\begin{array}{l}\text { Judul } \\
\text { Berita }\end{array}$ \\
\hline 1. & $\begin{array}{l}\text { Senin, } 22 \text { Juli } \\
2013\end{array}$ & $\begin{array}{l}\text { PPP: Rakyat Tergangou } \\
\text { Survei Pesalla1 }\end{array}$ \\
\hline 2. & $\begin{array}{l}\text { Kannis, 25 Juli } \\
2013\end{array}$ & $\begin{array}{l}\text { Marwan: } 2014 \text { Monnentunn } \\
\text { Konsolidasi Nasional }\end{array}$ \\
\hline 3. & $\begin{array}{l}\text { Kamis, } 25 \text { Juli } \\
2013\end{array}$ & $\begin{array}{l}\text { Said Agil 'l'cgaskan PKB } \\
\text { Partainya NU }\end{array}$ \\
\hline 4. & $\begin{array}{l}\text { Kamis, } 25 \text { Jisli } \\
2013\end{array}$ & $\begin{array}{l}\text { Khofifah Ungkap Digaan } \\
\text { Kartel Politik }\end{array}$ \\
\hline 5. & $\begin{array}{l}\text { Seninin, } 29 \text { Juli } \\
2013\end{array}$ & Khofifialı Segera Ditetapkan \\
\hline
\end{tabular}

Sumber Berita

Romahurmuziy (Sekretaris Jendral Partai Persatuan Peribariguria11)

Ketua Fraksi Partai Kebangkitan Bangsa DPR RI Marwan Ja'far

Said Agil Siroj (Kctıa L_mum Pcngıırıı Besar Nahdlatıl Ulama) \& Kctı Umum PKB Muhaimin Iskandar Khofifah Indar Parawansa (calon (Gubernur Jawa Timur), Herman (Dilo Hasibuan (kuasa hukum Khalilahi), Ferry Kunnia Rizkiyan1syatı (Kunisioner KPU) Tri Calıya Indra Pennana (Ketua Majelis IIakinı PTUN) 
Tabel 3: Sampel Berita Koran SINDO

\begin{tabular}{|c|c|c|c|}
\hline NO & $\begin{array}{l}\text { Tanggal } \\
\text { Tayang }\end{array}$ & $\begin{array}{l}\text { Judul } \\
\text { Berita }\end{array}$ & Sumber Berita \\
\hline 1. & $\begin{array}{l}\text { Selasa, } 11 \\
\text { Mei } 2013\end{array}$ & $\begin{array}{l}\text { Drama Perlawanan } \\
\text { PKS }\end{array}$ & $\begin{array}{l}\text { Abraham Samad (Ketua Komisi lemberantasan } \\
\text { Korupsi) }\end{array}$ \\
\hline 2. & $\begin{array}{l}\text { Kamis, } 11 \\
\text { Juli } 2013\end{array}$ & $\begin{array}{l}\text { Fahri Ancam Ingkap } \\
\text { Peran Sudi Silalahi }\end{array}$ & $\begin{array}{l}\text { Fah ri Hamzah (Wakil Sckrctaris Jenderal PKS, } \\
\text { Margarito (Pengamat I Iukum) }\end{array}$ \\
\hline 3. & $\begin{array}{l}\text { Rabu 24 Juli } \\
2013\end{array}$ & $\begin{array}{l}\text { PKB Buka Pcluang } \\
\text { Mahfud- } \Lambda \text { li Masykur }\end{array}$ & $\begin{array}{l}\text { Muhaimin Iskandar (Kctua Umum PKB), Mahfud MD } \\
\text { (Mantan Ketua MK) }\end{array}$ \\
\hline 4. & $\begin{array}{l}\text { Selasa, } 30 \text { Juli } \\
2013\end{array}$ & $\begin{array}{l}\text { Indoguna Setor Rp } 1 \\
\text { Miliar untuk PKS }\end{array}$ & $\begin{array}{l}\text { Maria Flizabeth I iman (pemilik PT Indoguna } \\
\text { Utama), Luth fi Hasan Ishaaq, Made Hendra (anggota } \\
\text { Majclis Hakinn 1), Elda Deviannc Adiningrat, } \\
\text { Suharyono (Kepala Fusat Perlindungan Varietas } \\
\text { Tanaman dan Perizinan Pertanian Kementan), Hatta } \\
\text { Rajasa (Mcnko Porckonomian), Yahdi Aldi Harap } \\
\text { (Wakil Sekretaris Jenderal D)PP PAN) }\end{array}$ \\
\hline 5. & $\begin{array}{l}\text { Selasa, } 30 \text { Juli } \\
2013\end{array}$ & $\begin{array}{l}\text { Khoffah Optimis } \\
\text { DKPP Kcrnl alikan } \\
\text { Haknya }\end{array}$ & $\begin{array}{l}\text { Khofifah Indar Parawansa (calon Gubemur Jawa } \\
\text { Timur) }\end{array}$ \\
\hline
\end{tabular}

Dari sampel pemberitaan yang dilakukan Harian Republika dan Sindo mengenai konstruksi citra partai-partai Islam atau berbasis massa Islam diperoleh karakteristik sebagai berikut:

a. Dari segi nara sumber berita baik Harian Republika maupun Sindo tampaknya cukup beragam bukan hanya dari kalangan politisi dalam hal ini pengurus partai-partai Islam atau berbasis massa Islam seperti Marwan Jafat (Ketua DPP PKB), Romahurmuziy (Sekretaris Jendral Partai Persatuan Pembangunan), melainkan juga dari kalangan lainnya seperti Jimly Asshiddiqie (Ketua Dewan Kehormatan Penyelenggara Pemilu DKPP), Said Agil Siroj (Ketua Umum Pengurus Besar Nahdlatul Ulama) \& Ketua Umum PKB Muhaimin Iskandar dan sebagainya. Hal ini cukup baik karena memberikan perspektif yang luas terhadap kasus yang menimpa partai-partai Islam atau berbasis massa Islam.

b. Berita umumnya model stright news (berita langsung), artinya berita yang menekankan pada berita cepat dan menyesuaikan dengan dinamika yang terjadi atau sedang berlangsung. Dengan kata lain, pemberitaan ini mengandalkan pada pandangan atau pernyataan narasumber, tanpa banyak melakukan investigasi.

Karakteristik pemberitaan seperti di atas dapat dilihat pada salah contoh pemberitaan yang dilakukan Harian Republika dan Sindo dengan berdasarkan analisis wacana Van Dijk, yaitu sebagai berikut: 


\section{Tabel 4: PPP, Rakyat Terganggu Survei Pesanan (Republika, 22 Juli 2013)}

\begin{tabular}{|c|c|c|}
\hline Elemen & Sub elemen & Isi \\
\hline l'cmatik & $\begin{array}{l}\text { PPP: Rakyat I'crganggu Survei } \\
\text { Pesanan }\end{array}$ & $\begin{array}{l}\text { PPP kcbcratan jika banyak lembaga survei yang hanya menggiring opini } \\
\text { publik pada kepentingan partai tertennı }\end{array}$ \\
\hline Skemalik & $\begin{array}{l}\text { Skema: lead (Romahurnuziy } \\
\text { mengatakan bahwa rakyat } \\
\text { terganggu olch survci clclstabilitas } \\
\text { pesanan yang menggiring pada } \\
\text { opini publik tertentu) } \\
\text { Pernyataan langsung } \\
\text { Romahurmuziy } \\
\text { Usulan Romahurmuziy } \\
\text { Penegasan Romahurmuziy }\end{array}$ & 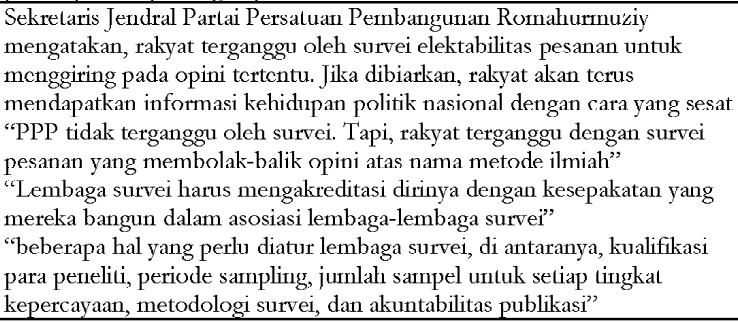 \\
\hline \multirow[t]{3}{*}{ Semantik } & $\begin{array}{l}\text { T.atar: Survei Pesanan Mengganggı } \\
\text { Opini Publik } \\
\text { Detil: kutipan langsung dari } \\
\text { Romahurmuziy yang mengatakan } \\
\text { bahwa rakyat lerganggu dengan } \\
\text { survei pesanan yang membolak- } \\
\text { balik opini atas nanna molode } \\
\text { ilmiah }\end{array}$ & $\begin{array}{l}\text { Jika survei elektahilitas pesanan dihiarkan, rakyat akan tenns mendaparkan } \\
\text { informasi kchidupan politils yang menyesatkan Romahirmuziy dengan } \\
\text { gamblang mengomentari lembaga-lembaga survei yang dipesan oleh partai } \\
\text { politik tertentu }\end{array}$ \\
\hline & $\begin{array}{l}\text { Maksud: Pertama, bahwa rakyat } \\
\text { terganggu oleh survei elektabilitas } \\
\text { pcsanan untuk monggiring pada } \\
\text { opini tertentu. } \\
\text { Kedua, seharusnya lembaga survei } \\
\text { diakruditasi. }\end{array}$ & $\begin{array}{l}\text { Lcubaya survei harus mengakreditasi dirinya deugan kescpakalau yauy } \\
\text { mereka bangun dalam asosiasi lembag-lembaga survei }\end{array}$ \\
\hline & $\begin{array}{l}\text { Kctiga, pcrlu adanya aturan yang } \\
\text { menganir lembaga survey }\end{array}$ & $\begin{array}{l}\text { Peherapa hal yang perlu dianı lembaga survei, di antaranya, kualifikasi } \\
\text { para pencliti, periode sampling, jumlah sampel untuk setiap tingkat } \\
\text { kepercayaan, melodelogi survei, dan akuntabilitas publikasi }\end{array}$ \\
\hline \multirow[t]{4}{*}{ Sintaksis } & Koherensi: ada & $\begin{array}{l}\text { Fakta bahwa setiap hasil dari lembaga survei yang menempatkan partai- } \\
\text { partai Islam di luar posisi tiga besar. } \\
\text { Domgan pertanyaan "apakalı masyarakat percaya pada survei atau } \\
\text { masyarakat memang tidak pernah percaya. Ini penting sebagai bentık } \\
\text { kejujuran keberadaan lembaga survei yang mengklam menggunakan } \\
\text { metode ilmiah }\end{array}$ \\
\hline & & $\begin{array}{l}\text { Jika lembaga-lembaga survei banyak yang dipesan, maka rakyat merasa } \\
\text { terganggu oleh elektabilitas pesanan yang menggiring pada opini tertentu }\end{array}$ \\
\hline & Bentuk Kalimat: berpikir logis & Menurut dia, heherapa hal yang perlu dianur lembaga survei.... \\
\hline & Kata Ganti: "dia" dan "1a" & $\begin{array}{l}\text { Ta menambahkan, perlu dilakıkan survei atas tingkat kepercayaan } \\
\text { masyarakat terhadap survey }\end{array}$ \\
\hline Stilistik & $\begin{array}{l}\text { Pilihan kata yang digunakan mudah } \\
\text { dipahami dengan menjelaskan } \\
\text { akronim, tidak menggunakan istilah } \\
\text { asiug }\end{array}$ & Partai Persatuan Pembangunan (FPP) Ilewan Pimpinan Pusat (I)PP) \\
\hline Retoris & $\begin{array}{l}\text { Grafis: tidak ada } \\
\text { Melafora: lidak ada }\end{array}$ & \\
\hline
\end{tabular}


Tabel 5: Indoguna Setor Rp 1 Miliar untuk PKS (Sindo, Selasa 30 Juli 2013)

\begin{tabular}{|c|c|c|}
\hline Elemen & Sub clemen & Isi \\
\hline Tematik & Indoguna Setor Rp 1 Miliar untuk PKS & $\begin{array}{l}\text { PT Indoguna Utama (IU) memberikan Rp } 1 \text { miliar untuk biaya } \\
\text { safari dakwah Partai Keadilan Sejahtera (TKS). Dana tersebut } \\
\text { diterima mclalui terdakwa Ahmad l'athanah }\end{array}$ \\
\hline \multirow[t]{5}{*}{ Skematik } & $\begin{array}{l}\text { Skema: lead PT Indoguna Utama (IU) } \\
\text { mombcrikan Rp } 1 \text { miliar untuls biaya } \\
\text { safari dakwah Partai Keadilan Sejahtera } \\
\text { (PKS). Daua Lersebul ditcrima melalui } \\
\text { terdakwa Ahmad Fathanah }\end{array}$ & $\begin{array}{l}\text { PT Indoguna Utama (IU) memberikan Rp } 1 \text { miliar untuk biaya } \\
\text { safari dalswah Partai Kcadilan Scjahtcra (PKS). Dana tcrscbut } \\
\text { diterima melalui terdakwa Ahmad Fathanah }\end{array}$ \\
\hline & $\begin{array}{l}\text { Pernyataan langsung Maria Elizabeth } \\
\text { Liman }\end{array}$ & $\begin{array}{l}\text { "Ahrnad Fathanah yang meminta untuk salari dakwah. Di kasihh } \\
\text { ke Fathanah tidak ada kaitannya dengan Luthfi. Itu untuk safari } \\
\text { dakwah dan kemantusiaan, ilu biasa". }\end{array}$ \\
\hline & Pcmbcibcran peristiwa & 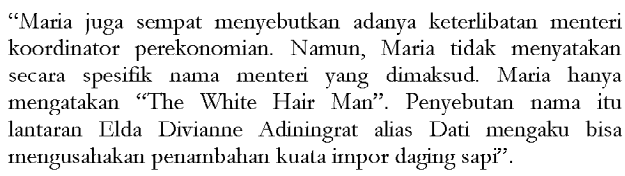 \\
\hline & & $\begin{array}{l}\text { Maria mcuyanugupi mocupucluntorkan darı R R } 1 \text { miliar untuk } \\
\text { kepentingan safari dakwah PKS }\end{array}$ \\
\hline & Penegasan Maria Flizaheth Timan & \\
\hline \multirow[t]{3}{*}{ Semanlik } & $\begin{array}{l}\text { Talar: PT Indogguna (IIJ) memberikan Rp } \\
1 \text { miliar untuk biaya safari dakwah Partai } \\
\text { Keadilau Scjalıtera (PKS). Daua tersebut } \\
\text { diterima melalui terdakwa Ahmad } \\
\text { Fallaalah. }\end{array}$ & $\begin{array}{l}\text { PT Indoguna (IV) memberikan Rp } 1 \text { miliar unltuk biaya salari } \\
\text { dakwah Partai Keadilan Sejahtera (PKS). Dana tersebut diterima } \\
\text { melalui kcrdakwa Alunad Falhaual.. }\end{array}$ \\
\hline & $\begin{array}{l}\text { Detil: Mcngcnai uang Rp } 1 \text { miliar yang } \\
\text { diberikan PT IU berdasarkan permintaan } \\
\text { Almmad lathanah untuk kepentingan } \\
\text { salari dakwah PKS di Medan, Maria } \\
\text { membantah uang itu untuk Luthfi. }\end{array}$ & $\begin{array}{l}\text { Mcngenai uang lRp } 1 \text { miliar yang dibcrikan } \text { Y'L }^{\prime} \text { IU bcrdasarkan } \\
\text { permintaan Ahmad Fathanah untuk kepentinganl safari dakwah } \\
\text { PKS di Medan, Maria membantah uang itu untuk Luthfi. }\end{array}$ \\
\hline & $\begin{array}{l}\text { Maksud: Membeberkan uang yang } \\
\text { dikcluarkan PT Indoguna Utama } \\
\text { sehanyak Rp I miliar untuk kepentingan } \\
\text { safari dakwah Partai Kcadilan Scjahtera. }\end{array}$ & $\begin{array}{l}\text { Membeberkan uang yang dikeluarkan PT Indogina Utama } \\
\text { scbanyak } R_{p} 1 \text { miliar untuk kepentingan safari dalkwaln Partai } \\
\text { Keadilan Sejahtera. }\end{array}$ \\
\hline \multirow[t]{4}{*}{ Sintaksis } & Koherensi: ada & $\begin{array}{l}\text { Maria Jusiru menyalahkan Komisaris PT Radina Niaga Mulia } \\
\text { Elda L havianne Adiningrat dalam pengurusan penambahan kuota } \\
\text { laging impor daying sapi. Dia mucuyklaim Elda merupakan ulak } \\
\text { dari semua penambahan kunta termasuk pertemuan di Medan. }\end{array}$ \\
\hline & Bentuk Kalimat: berpikir logis & 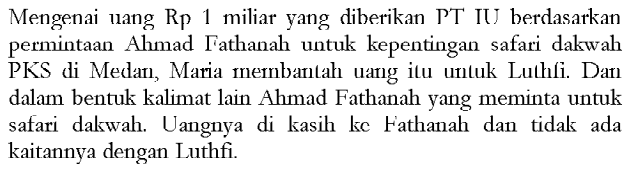 \\
\hline & & $\begin{array}{l}\text { "dia mengklaim Fida merupakan otak dari semua penambahan } \\
\text { kuota termasuk pertcmuan di Medan". }\end{array}$ \\
\hline & Kata Ganti: "dia" & \\
\hline Stilistik & $\begin{array}{l}\text { Pilihan kata yang digunakan mudah } \\
\text { dipahami dcngan menjclaskan alkronim, } \\
\text { tidak menggunakan istilah asing }\end{array}$ & PKS, Tipikor, IU, \\
\hline Retoris & $\begin{array}{l}\text { Grafis: Lidak ada } \\
\text { Metafora: 'I'he White I lair Man, si Uban }\end{array}$ & $\begin{array}{l}\text { Maria hanny mengatakan "The White Hair Man" sedangkan Elda } \\
\text { menyebutnya dengan istilah "si uban" }\end{array}$ \\
\hline
\end{tabular}


Konstruksi citra partai Islam pada pemilu 2014... (Iding Rosyidin dan Gun Gun Heryanto)

\section{Kognisi sosial pemberitaan}

Dari sisi kognisi sosial, terdapat perbedaan antara Harian Republika dan Sindo dalam memproduksi pemberitaan tentang partai-partai Islam atau berbasis massa Islam. Republika tampaknya berusaha untuk mengkounter setiap pemberitaan yang terkait dengan citra partaipartai Islam. Dalam hal ini, Republika yang notabene koran yang diidentikkan dengan kalangan Islam sehingga kerap disebut Koran umat memang memiliki keinginan agar partai-partai Islam tersebut tidak mengalami keterpurukan pada Pemilu 2014. Sedangkan Sindo dengan slogannya "sumber referensi terpercaya" tidak terlalu memfokuskan diri pada kondisi partai Islam. Sebagai koran nasional yang memang lahir dari kepentingan kelompok nasional, Sindo tidak terlalu memberikan perhatian yang besar terhadap apakah citra partai Islam mengalami kemerosotan ataukah tidak.

Dalam konteks fikih siyasah, Republika yang memang diidentikkan dengan koran Islam atau setidaknya mencerminkan aspirasi umat Islam tampaknya memandang dirinya sebagai entitas yang diharapkan juga mampu ikut mengurusi kemasalahatan umat Islam. Dengan berusaha selalu mengkounter pemberitaan miring tentang partai-partai Islam, Republik seolah ingin menjaga agar partai-partai Islam dan juga elite-elite tetap mendapatkan kepercayaan dari umat sehingga dapat berbuat yang terbaik bagi kemasalahatan umat.

\section{Konteks sosial pemberitaan}

Adapun dari sisi konteks sosial, konstruksi citra pemberitaan partai-partai Islam di Harian Republika dan Sindo dilatarbelakangi oleh momentum penyelenggaraan Pemilu 2014 yang tinggal beberapa bulan lagi. Namun terdapat perbedaan dalam target yang ingin diperoleh oleh masing-masing harian tersebut dari konstruksi pemberitaan tentang partai-partai Islam. Harian Republika mengakui bahwa memang mencoba mengkonstruksi Partai Islam sedemikian rupa menjelang Pemilu 2014. Target dari Harian Republika adalah tetap konsisten menyandang koran umat. Meskipun posisi Republika lemah dengan kasus yang melibatkan presiden salah satu partai Islam, namun Republika tetap berusaha mengkounter semua isu tentang Partai Islam. Sementara Sindo tidaklah terlalu terfokus pada Partai Islam. Koran Sindo cenderung netral sehingga tidak membedakan partai Islam atau Partai Non Islam. 
Namun demikian Harian Republika tampaknya lebih menekankan pada upaya mempertahan citra partai Islam atau berbasis massa Islam dari sisi institusinya, bukan pada tokoh-tokohnya. Dengan kata lain, terhadap tokoh-tokoh partai Islam yang terbukti melakukan pelanggaran seperti korupsi, maka tidak ada alasan bagi harian ini, misalnya, untuk memberitakannya dalam perspektif yang sifatnya membela. Di sini sikap dan pandangan Republika sejalan dengan konsep karakteristik kepemimpinan Islam dari alMawardi, yakni pemimpin atau elite Islam harus adil dan memiliki pandangan yang menekankan tentang pengaturan urusan umat dan kemasalatannya. Pemimpin korups jelas bertentangan dengan karakteristik tersebut.

Dari perspektif teori hirarki pengaruh ada dua level yang tampak cukup menonjol dalam mempengaruhi pemberitaan, yaitu level organisasi media dan ideologi. Pada level organisasi media, misalnya, keberadaan pemilik baik individu maupun korporasi jelas sangat berpengaruh terutama jika menyangkut kepentingan sang pemilik. Harian Sindo yang berada di bawah naungan konglomerasi MNC Group milik Hary Tanoesoedibjo yang kini telah menjadi calon wakil presiden mendampingi Wiranto dari Partai Hanura jelas selalu berusaha melakukan pemberitaan yang tidak akan merugikan kepentingan Hary Tanoe ataupun partainya. Meskipun produksi pemberitaan dapat dilakukan di ruang redaksi, tetapi para redaktur tentu mempertimbangkan betul apakah bersinggungan dengan kepentingan pemilik media ataukah tidak.

Sementara pada level ideologi dalam pengertian cara pandang media sebagai perusahaan yang menghendaki perolehan profit yang tinggi pengaruhnya cukup terasa dengan menyediakan lahan khusus terkait dengan pemberitaan partai-partai Islam meskipun terdapat sedikit penekanan dari Harian Republika dan Sindo. Memang terdapat perbedaan cukup menonjol dalam hal ini. Jika pada Harian Sindo masalah profit merupakan hal yang dominan, sementara pada Harian Republika, selain profit juga mereka agaknya memiliki keinginan agar partai-partai Islam atau berbasis massa Islam tersebut meskipun tidak berjaya tetapi setidaknya tidak mengalami keterpurukan pada Pemilu 2014.

\section{Penutup}

Tulisan ini berusaha untuk melihat bagaimana konstruksi citra partai Islam pada Pemilu 2014 khususnya di Harian Republika dan Sindo di mana ditemukan bahwa meskipun 
mendapatkan tempat di kedua harian nasional tersebut, tetapi terdapat perbedaan dalam sejumlah hal. Misalnya dari sisi kognisi sosial. Republika tampaknya berusaha untuk mengkounter setiap pemberitaan yang terkait dengan citra partai-partai Islam. Harian Republika mengakui bahwa memang mencoba mengkonstruksi Partai Islam sedemikian rupa menjelang Pemilu 2014. Target dari Harian Republika adalah tetap konsisten menyandang koran umat. Meskipun posisi Republika lemah dengan kasus yang melibatkan presiden salah satu partai Islam, namun Republika tetap berusaha mengkounter semua isu tentang Partai Islam.

Dalam konteks fikih siyasah, Republika yang memang diidentikkan dengan koran Islam atau setidaknya mencerminkan aspirasi umat Islam tampaknya memandang dirinya sebagai entitas yang diharapkan juga mampu ikut mengurusi kemasalahatan umat Islam. Dengan berusaha selalu mengkounter pemberitaan miring tentang partai-partai Islam, Republik seolah ingin menjaga agar partai-partai Islam dan juga elite-elite tetap mendapatkan kepercayaan dari umat sehingga dapat berbuat yang terbaik bagi kemasalahatan umat.

Namun Republika tidak membela partai-partai Islam secara membabi buta, misalnya pada tokoh-tokohnya. Terhadap tokoh-tokoh partai Islam yang terbukti melakukan pelanggaran seperti korupsi, maka tidak ada alasan bagi harian ini, misalnya, untuk memberitakannya dalam perspektif yang sifatnya membela. Di sini sikap dan pandangan Republika sejalan dengan konsep karakteristik kepemimpinan Islam dari al-Mawardi, yakni pemimpin atau elite Islam harus adil dan memiliki pandangan yang menekankan tentang pengaturan urusan umat dan kemasalatannya. Pemimpin korups jelas bertentangan dengan karakteristik tersebut.

Sedangkan Sindo tidak terlalu memfokuskan diri pada kondisi partai Islam. Dari sisi konteks sosial, konstruksi citra pemberitaan partai-partai Islam. Pemberitaan mengenai partaipartai Islam atau berbasis massa Islam juga tidak terlepas dari pengaruh beberapa faktor yang menurut teori hierarki pengaruh dikelompokkan ke dalam lima level, dalam hal ini level organisai media dan ideologi pengaruhnya lebih menonjol. 
ljtihad, Jurnal Wacana Hukum Islam dan Kemanusiaan, Volume 15, No. 1, Juni 2015: 1-20

\section{Daftar pustaka}

Al-Mawardi. al-Aḥkam al-Sultāniyyah. Beirut: Dār al-Fikr, t.th.

Arikunto, Suharsimi. Prosedur Penelitian: Suatu Pendekatan Praktek, cet-5. Jakarta: PT. Rineka Cipta, 2002.

Boyd Barrett, Oliver and Chris Newbold eds. Approaches to Media: a Reader. London: Arnold, 1995.

Basrowi, Sukidin. Metode Penelitian Kualitatif Perspektif Mikro. Surabaya: Insan Cendekia, 2002.

Berger, Peter L dan Thomas Luckman. Tafsir Sosial atas Kenyataan. Jakarta: LP3S, 1990.

Bungin, Burhan. Sosiologi Komunikasi: Teori, Paradigma dan Diskursus. Jakarta: Prenada Media, 2002.

Denzin, Norman K \& Lincoln, Yvonna S. 2009. Handbook of Qualitative Research, Dariyanto dkk terj. Yogyakarta: Pustaka Pelajar Teknologi Komunikasi di Masyarakat. Jakarta: Kencana, 2007.

Eriyanto. Analisis Framing: Konstruksi, Ideologi dan Politik Media. Yogyakarta: LkiS, 2001.

Hidayat, Dedy N. "Konstruksi Sosial Industri Penyiaran: Kerangka Teori Mengamati Pertarungan di Sektor Penyiaran", Makalah dalam diskusi "UU Penyiaran, KPI dan Kebebasan Pers, di Salemba 8 Maret 2003.

Mosco, Vincent. The Political Economi of Communication. London: SAGE Publication, 1996.

Mulyana, Deddy. Metodologi Penelitian Kualitatif: Paradigma Baru Ilmu Komunikasi dan Ilmu Sosial Lainnya. Cetkan Ke- 5. Bandung: Remaja Rosdakarya, 2006.

Pamela J. Shoemaker \& Stephen D. Reese. Mediating The Message: Theories of Influences on Mass Media Content. Second Edition. USA: Longman Publishers, 1996.

Pulungan, J. Suyuthi. Fikih Siyasah, Ajaran, Sejarah, dan Pemikiran. Jakarta: PT Raja Grafindo Persada, 2002.

Sobur, Alex. Analisis Teks Media: Suatu Pengantar untuk. Analisis Wacana, Analisis Semiotika dan Analisis Framing. Bandung: PT.Remaja Rosdakarya, 2010. 